\title{
ASSESSMENT OF SERVICE QUALITY IN THE HOTEL INDUSTRY: USE OF FUZZY HYBRID METHODOLOGIES
}

\author{
Submission: $18 / 11 / 2016$ \\ Accept: $27 / 09 / 2018$ \\ Nara Medianeira Stefano ${ }^{1}$ \\ Izabel Cristina Zattar ${ }^{2}$ \\ Nelson Casarotto Filho ${ }^{3}$
}

\begin{abstract}
Considering that, service quality is an abstract and elusive construct because of three characteristics of services: intangibility, heterogeneity, and inseparability of production and consumption. Thus, we define service quality as perceived by the customer. Therefore, for service providing organizations the interpretation of customer needs is critical. The good performance in services strengthens competitiveness and establish a relationship with the customer, consolidating the brand, communication with the market. In this context, study aimed to assess the services quality in large hotel located in Santa Catarina - Brazil, with participation of 187 guests. We used the SERVQUAL method to collect data on a questionnaire of dimensions of quality. To calculate the expected weights and perception was used FAHP (Fuzzy Analytic Hierarchy Process). As a result, these aspects are presented where the expectation of the guests regarding the service is greater than that found reality, allowing thus the company strategically align its future investments.
\end{abstract}

Keywords: Service quality. FSERVQUAL. FAHP. Hotel.

\footnotetext{
1 Institution / Affiliation: Universidade Federal de Santa Catarina - UFSC. Florianópolis, Santa Catarina, Brasil. Doctorate in Production Engineering. E-mail: stefano.nara@gmail.com. ORCID: https://orcid.org/0000-0001-8786-8934

2 Institution / Affiliation: Universidade Federal do Paraná - UFPR. Curitiba, Paraná. Doctorate in Production Engineering.

E-mail: izabel.zattar@gmail.com

3 Institution / Affiliation: Universidade Federal de Santa Catarina - UFSC. City, State, Country: Florianópolis, Santa Catarina, Brazil

Biography Summary: Doctorate in Production Engineering from Universidade Federal de Santa Catarina.

E-mail: ncasarottofilho@gmail.com. ORCID: id https://orcid.org/0000-0001-7159-1117
}

Rev. AdM. UFSM, SANTA MARIA, V. 13, NúMERo 1, P. 40-57, 2020 


\section{RESUMO}

Considerando que, a qualidade dos serviço é um construto abstrato e indescritível, devido a três características dos serviços: intangibilidade, heterogeneidade e inseparabilidade da produção e do consumo. Assim, definimos a qualidade do serviço como aquela percebido pelo cliente. Assim, para as organizações prestadoras de serviços, a interpretação das necessidades do cliente é crítica. O bom desempenho nos serviços fortalece a competitividade e estabelece um relacionamento com o cliente, consolidando a marca, a comunicação com o mercado. Nesse contexto, o estudo teve como objetivo avaliar a qualidade dos serviços em um grande hotel localizado em Santa Catarina - Brasil, com a participação de 187 hóspedes. Utilizamos o método SERVQUAL para coletar dados em um questionário de dimensões de qualidade. Para calcular os pesos esperados e a percepção foi utilizado o FAHP (Fuzzy Analytic Hierarchy Process). Como resultado, são apresentados aspectos em que a expectativa dos hóspedes em relação ao serviço é superior à realidade encontrada, permitindo assim que a empresa alinhe estrategicamente seus futuros investimentos.

Palavras-chave: Qualidade de serviço; FSERVQUAL, FAHP. hotel.

\section{INTRODUCTION}

The importance of service quality for business performance has been recognized in literature through the direct effect on customer satisfaction and the indirect effect on customer loyalty (PARASURAMAN et al., 1985; WILKINS et al., 2007). Quality is a term that is considered indicative high level of customer satisfaction and refers to factors that characterize a product or service. Service quality (UDO et al., 2011) is an elusive and abstract construct that is difficult to define and measure.

The quality of service could be considered as composite of multiple attributes. It is not, only, composed of tangible attributes, but also the intangible and subjective attributes such as safety, comfort, and satisfaction, which are difficult to measure accurately. Considering the characteristics of services (intangibility, inseparability, heterogeneity and perishability), it becomes difficult to measure its quality.

A number of information science researchers manifest that service quality is an important variable and affects the successful operation of service enterprise (RANDS, 1992; FERGUSON and ZAWACKI, 1993; KETTINGER and LEE, 1994; PITT et al., 1995; YEE et al., 2010; CALABRESE, 2012; SANDMANN, 2013; ZEHENDNER and FEILLET, 2014; ZHANG and XING, 2015). Thus, one of the definitions found in literature describes the service quality as the ability to meet customer needs. The assessment of perceived (SNOJ et al., 2004; DAS, 2014) quality is realized by the customer during or after the service delivery process; and is determined by comparing perceived quality and that expected by the customer.

Satisfaction is an immediate response to consumption, while service quality is interpreted as the overall impression of a customer's judgment concerning service provided (BITNER and HUBBERT, 1994; CULIBERG, 2010). Service quality is influenced by expected service and perceived service. If services are received as expected, the service quality is satisfactory, but if the services received exceed their expectations, customers will be delighted, and will perceive service quality as excellent and vice versa (PARASURAMAN et al., 1985).

Since service industry contains intangibility, inseparability and heterogeneity, it makes people more difficult to measure service quality. Since the evaluation is resulted from evaluator's view of linguistic variables, it must be conducted in an uncertain, fuzzy environment. In order to overcome the issue, fuzzy set theory is invited into the measurement of performance. Fuzzy set theory aids in measuring the ambiguity of concepts that are associated with human being's subjective judgment (BÜYÜKÖZKAN et al., 2011). 
In this way, to measure the quality of service, conventional measurement makes use of cardinal or ordinal scales. Criticism of scale based on the measurement is that the score does not necessarily represent the user's preference. Humans and preference judgments are often vague and cannot estimate their preference with an exact numerical value.

Therefore, the usage of linguistic terms to describe the desired value and the weight of importance of the criteria (i.e. very low, low, fair, high, etc.) is recommended. Because of the existing imprecision in this process, fuzzy set theory is an appropriate method for dealing with uncertainty. Fuzzy logic provides tools able to capture vague information, generally described in a natural language, and convert it to a numeric format, easily manipulated by computers. The systems are based on fuzzy reasoning ability similar to the human form.

This paper aimed to evaluate the quality of a large hotel located in Santa Catarina, Brazil. The first step involves development of a SERVQUAL based questionnaire to collect data for evaluated service quality in the hotel industry. Fuzzy SERVQUAL (FSERVQUAL) was used to calculate the $\mathrm{Gap}_{5}$ (discrepancy between perception and expectation - perceived quality). The Fuzzy Analytic Hierarchy Process (FAHP) method was applied to calculate the relative weights of the criteria/sub-criteria selected that affect services quality.

This paper is organized into five sessions. The context of the research is described in session 1. Session 2 explains the determinants of service quality and SERVQUAL Scale; session 3 shows methodology. In session 4, its application and results (case study) are described. And finally, session 5 consists of the found conclusions.

\section{DETERMINANTS OF SERVICE QUALITY}

The definition of service concept is a fundamental part of the strategic advantage seeking processes of service design, service development and service innovation (GOLDSTEIN et al., 2002; STUART and TAX, 2004; BÜYÜKÖZKAN et al., 2011; CHUANG and LIN, 2015).

Because it is different from physical goods, it is more difficult to define service. Services are spread into a lot of areas; like services given in beauty salons or services given from insurance companies. And also, because they comprise a lot of heterogeneous activities, services become more complex and defining the services becomes more and more difficult. Although the difficulties mentioned today, it can be seen that the concept of service is defined by many researchers.

For each type of service (LUPO, 2013; 2015; CHARLES and KUMAR, 2014), there can be a specific set of quality determinants. Various authors have tried to define a generic set of determinants that applies to all types of service. It can be defined as a set of parameters for service quality based on some authors (PARASURAMAN et al., 1985, 1988, 1994; GHOBADIAN et al., 1994; JOHNSTON, 1995, 2005, 2008, GRÖNROOS, 2004; Liu et al., 2015; SAM; HAMIDU; DANIELS, 2016; REZAl et al, 2018):

- Tangibles - these include the state of facilitating goods, physical condition of the buildings and the environment, appearance of personnel, and condition of equipment.

- Customization - the willingness and ability to adjust the service to meet the needs of the customer.

- Access - the ease of approachability and contact.

- Communication - keeping customers informed about the service in a language that they can understand and listening to the customers.

- Understanding/knowing the customer - this involves trying to understand the cus- 
tomer's needs and specific requirements, providing individualized attention, and recognizing the regular customer (an important determinant of quality in high-contact customized services).

- Security - the freedom from danger, risk and doubt. It involves physical safety, financial security and confidentiality.

- Courtesy - the politeness, respect, consideration and friendliness shown to the customers by the contact personnel.

- Competence - employees should possess the necessary skills, knowledge and information to perform the service effectively.

- Credibility - the extent to which the service is believed and trusted. The service provider's name and reputation, and the personal traits of front line employees all contribute to credibility.

- Reliability - the ability to provide the pledged service on time, accurately and dependably.

- Responsiveness - the ability to deal effectively with complaints and promptness of the service.

- Cost - the price paid for the service. Although the price is competitive criteria that has a strong influence on the strategic positioning of an organization which may consider price and quality as distinct characteristics.

Each type of service may have determinants that are considered critical to the organization. The perception of quality and the subsequent evaluation of the service are given regarding the determinants considered most important to the client in each moment of truth. Service quality is influenced by expected service and perceived service. If, services are received as expected, the service quality is satisfactory, but if the services received exceed their expectations, customers will be delighted, and will perceive service quality as excellent. The opposite can be said for customers who receive less than satisfactory service quality.

Measuring the quality of services is a challenge, for satisfaction is determined by many intangibles instead of products with tangibles characteristics objectively measured. Hence, the importance and the utility value of each determinant of quality is dependent on the nature of the service.

\subsection{Servqual Scale}

Many service quality (ROGER-MONZÓ et al., 2015; CABER and ALBAYRAK, 2018) models have been proposed. Among these models, the most enduringly popular, widely cited and best researched method of evaluating service quality is SERVQUAL, developed by Parasuraman et al. $(1985,1988)$. The most commonly used measure of service quality has been the SERVQUAL scale (BASFIRINCI and MITRA, 2015; LIU et al., 2015) originally developed and refined (PARASURAMAN et al., 1985; 1988, 1994).

The resultant assessment instrument is SERVQUAL (for service quality), created as a means of tracking service quality across industries and determining the importance of key consumer perceptions and expectations (UDO et al., 2011). SERVQUAL has five main dimensions to measure service quality: tangibles, reliability, responsiveness, assurance, and empathy.

The items are presented in a five, seven or nine-point response format with anchors 'strongly agree' and 'strongly disagree' (Likert-type) (KANG and BRADLEY, 2002). Service quality is then measured by calculating the "gaps" between corresponding items, the difference between 
customers' perception and expectation (concise multiple item scale that contains 22 pairs) of service, as well as the dimensions of service.

The first step involves development of a questionnaire survey for measuring service quality. The questions were prepared using the service quality criteria proposed in SERVQUAL. To paper were using to this paper quality dimensions (to business hotels'):

- Tangibles - physical facilities, equipment, and appearance of personnel.

- Reliability - ability to perform the promised service dependably and accurately.

- Assurance - knowledge and courtesy of employees and their ability to inspire trust and confidence.

- Empathy - the amount of caring, individualized attention the firm provides its customers.

- Access - involves approachability and case contact.

For the study we used the Gap model (PARASURAMAN et al., 1985) to compare the perception and expectation. In fact, the SERVQUAL instrument is based on the 5 Gaps. These gaps on the service provider's side, which can impede delivery of services that consumers perceive to be of high quality, are:

- Gap 1 - difference between consumer expectations and management perceptions of consumer expectations.

- Gap 2 - difference between management perceptions of consumer expectations and service quality specifications.

- Gap 3 - discrepancy between service quality specifications and the service actually delivered.

- Gap 4-discrepancy between service delivery and what is communicated about the service to consumers.

- Gap 5 (service quality) Gap 5 = f (Gap 1, Gap 2, Gap 3, Gap 4) - difference between consumer expectations and perceptions. I.e. the quality that the consumer perceives in services is a function of the magnitude and direction of the gap between expected service and perceived service. This occurs when the expectation is not exceeded.

The SERVQUAL (LADHARI et al., 2011; BARABINO et al., 2012; CHOUDHURY, 2013; ALNSOUR et al., 2014; CHOUDHURY, 2015; OZRETIC-DOSEN and ZIZAK, 2015) scale used as a diagnostic technique for identifying, in various types of services, the strengths and weaknesses of the company, providing the basis for continuous improvement. It can also be used for various applications, including the identification of trends in service quality when applied regularly with customers.

Another application is in marketing to compare a service of its competitors, identifying dimensions of quality are superior to those competitors and which need improvement.

\section{METHODOLOGY}

The fuzzy set theory used in this paper was introduced (ZADEH, 1965) first. In this paper, a FSERVQUAL method and FAHP will be used to evaluate service quality in the hotel industry. 


\subsection{The arithmetic operations on fuzzy numbers}

Fuzzy set theory is a mathematical theory pioneered by Zadeh (1965), which is designed to model the vagueness or imprecision of human cognitive processes. If the uncertainty (fuzziness) of human decision-making is not taken into account, the results can be misleading.

The key idea of fuzzy set theory is that an element has a degree of membership in a fuzzy set (ZADEH, 1994; NEGOITA, 1985; ZIMMERMANN, 1996; LI and HUANG, 2009). A fuzzy set is defined by a membership function (all the information about a fuzzy set is described by its membership function maps elements (crisp inputs) in the universe of discourse (interval that contains all the possible input values) to elements (degree of membership) within a certain interval which is usually $[0,1])$.

If the value assigned is zero, the element does not belong to the set (it has no membership). If the value assigned is one, the element belongs completely to the set (it has total membership). Finally, if the value lies within the interval, the element has a certain degree of membership (belongs partially to the fuzzy set) (AYAĞ, 2005; BÜYÜKÖZKAN and ÇIFÇI, 2011, 2012).

The basic arithmetic operations (LI, 1999; CHOU et al., 2011; LIU et al., 2015) on fuzzy numbers are introduced as follows. Let $A_{1}=\left(c_{1}, a_{1}, b_{1}\right)$ is triangular fuzzy number and $A_{2}=\left(c_{2}\right.$, $\left.a_{2}, b_{2}\right)$ is also triangular fuzzy number.

Addition Operation $\left(A_{1}\right.$ and $\left.A_{2}\right)$ (Equation 1)

$$
A_{1}+A_{2}=\left(a_{1}+a_{2}, b_{1}+b_{2}, c_{1}+c_{2}\right)
$$

Subtraction Operation $\left(A_{1}\right.$ and $\left.A_{2}\right)$ (Equation 2)

$$
A_{1}-A_{2}=\left(a_{1}-c_{2}, b_{1}-b_{2}, c_{1}-a_{2}\right)
$$

Division Operation ( $r$ is real number) (Equation 3)

$$
\frac{A_{1}}{r}=\left(\frac{a_{1}}{r}, \frac{b_{1}}{r}, \frac{c_{1}}{r}\right)
$$

A fuzzy number is a special fuzzy set $A=\{(x, \mu \tilde{A}(x)), x \in R\}$, where $x$ takes values on the real line, $\mathrm{R}:-\infty<x<+\infty$ and $\mu \tilde{A}(x)$ is a continuous mapping from $\mathrm{R}$ to the closed interval $[0,1]$. A triangular fuzzy number denoted as $\tilde{A}=(l, m, u)$ where $l \leq m \leq u$ following triangular-type membership function (Equation 4):

$$
\mu_{A}(x)=\left\{\begin{array}{l}
0, x<1 \text { or } x>u \\
\frac{x-1}{m-l}, l \leq x \leq m \\
\frac{u-x}{u-m}, m \leq x \leq u
\end{array}\right.
$$




\subsection{Questionnaire design}

In this paper, the design questionnaire is based on the previous literatures and the interviews. The SERVQUAL questionnaire is the main base (Table 1 ).

Table 1. Questionnaire used in survey

\begin{tabular}{|c|c|}
\hline Criteria & Sub-criteria (Sc) \\
\hline \multirow{8}{*}{ Tangible } & Visually appealing (buildings and facilities). \\
\hline & Adequate capacity of the hotel units (dining rooms, meeting rooms, swimming pools, etc.). \\
\hline & $\begin{array}{l}\text { Modern equipment to looking good (air conditioning, furniture, elevator, communication de- } \\
\text { vices, etc.). }\end{array}$ \\
\hline & $\begin{array}{l}\text { The atmosphere and equipment are comfortable and appropriate for stay (beds, chairs, lou- } \\
\text { nges, etc. comfortable, clean and tranquil). }\end{array}$ \\
\hline & Works properly of equipment without causing breakdowns. \\
\hline & Adequate and sufficient of materials to services (soap, shampoo, towel, etc.). \\
\hline & Food and beverages served and prepared hygienically adequate and sufficient. \\
\hline & Good appearance of hotel employees (as uniforms and personal hygiene). \\
\hline \multirow{4}{*}{ Reliability } & Services realized as promised and accurate. \\
\hline & The hotel provides the services at the time it promises to do so. \\
\hline & It keeps accurate records (reservations, guest records, bills, orders, etc.). \\
\hline & Of the employees whenever necessary. \\
\hline \multirow{4}{*}{ Assurance } & The hotel to resolve guest's complaints and compensates for the inconveniences. \\
\hline & The hotel provides flexibility in services according to guests demands. \\
\hline & Consistency of services provided. \\
\hline & $\begin{array}{l}\text { Knowledge of employees about the work that are doing (professional abilities, foreign lan- } \\
\text { guage, communication abilities, etc.), provide information and assistance to guests. }\end{array}$ \\
\hline \multirow{4}{*}{ Empathy } & Employees give guests individualized attention that makes them feel special. \\
\hline & Employees understand the specific needs of guests \\
\hline & The hotel is convenient for disabled guests (necessary arrangements made for the disabled). \\
\hline & The hotel and its facilities have convenient hours to all their guests. \\
\hline \multirow[t]{2}{*}{ Access } & Easy access to the hotel (transportation, loading and unloading area, car parking area, etc.). \\
\hline & $\begin{array}{l}\text { Getting information about the facilities and services of the hotel is easy (reaching information } \\
\text { via phone, Internet, etc., direction signs, etc.) }\end{array}$ \\
\hline
\end{tabular}

Source: Adapted from Akbaba (2006)

Linguistic variables are used to rate the SERVQUAL questionnaire addressing expectation and perception. Specially, the linguistic variables for interviewee's perceptions consist of 'Very Poor; Poor; Fair; Good; Very Good'. In actual quantitative analysis process, we should convert the linguistic variables into triangular fuzzy numbers, as shown in Table 2.

Table 2. Linguistic variables for expectation and perception

\begin{tabular}{ccccc}
\hline Scale relative & $\begin{array}{c}\text { Linguistic variable (ex- } \\
\text { pectation) }\end{array}$ & $\begin{array}{c}\text { Membership } \\
\text { function }\end{array}$ & $\begin{array}{c}\text { Linguistic variable } \\
\text { (perception) }\end{array}$ & $\begin{array}{c}\text { Membership } \\
\text { function }\end{array}$ \\
\hline $\mathbf{1}$ & Very Low & $(0,1,2)$ & Very Poor & $(0,1,2)$ \\
$\mathbf{2}$ & Low & $(1,2,3)$ & Poor & $(1,2,3)$ \\
$\mathbf{3}$ & Fair & $(2,3,4)$ & Fair & $(2,3,4)$ \\
$\mathbf{4}$ & High & $(3,4,5)$ & Good & $(3,4,5)$ \\
$\mathbf{5}$ & Very High & $(4,5,5,5)$ & Very Good & $(4.5,5,5)$ \\
\hline
\end{tabular}


In the questionnaire, there are 5 dimensions and 22 items. The size of the sample is 187 and is characterized as simple random sampling. This sample provides accuracy and efficiency as well as being an easy procedure to be applied (because all elements of the population have the same probability of belonging to the sample).

The internal consistency test was performed by means of Cronbach's alpha. Internal consistency (TAVAKOL and DENNICK, 2011) describes the extent to which all the items in a test measure the same concept or construct and hence, connected to the inter-relatedness of the items within the test. Internal consistency should be determined before a test can be employed for research or examination purposes to ensure validity.

\subsection{Fuzzy SERVQUAL method}

The calculation procedure of fuzzy SERVQUAL introduce three steps (CHOU et al., 2011; LIU et al., 2015) (Equations 5 and 6).

$$
\begin{gathered}
T A_{\theta i}=\sum_{1}^{n} A_{\theta \dot{n}} \\
T A_{p i}=\sum_{1}^{n} A_{p i n}
\end{gathered}
$$

By using the Equations (1) and (5), the expectation of total service quality can be taken from all interviewees of service item i. Similarly, by the Equations (1) and (6), the perception of total service quality can be taken from all interviewees of service item $i$.

\subsection{Calculating the mean scores}

Considering fuzzy number $M A_{e i}$ as the average service quality expectations from all interviewees of service item $i$. Let fuzzy number $M A_{p i}$ be the average service quality perceptions from all interviewees of service item $i$ (Equations 7 and 8).

$$
\begin{aligned}
M A_{e i} & =\frac{T A_{e i}}{N} \\
M A_{p i} & =\frac{T A_{p i}}{N}
\end{aligned}
$$

By using, the Equations ( 3 ) and (7) the expectation of mean service quality can be calculated from all interviewees the service item i. In addition, Equations ( 3 ) and ( 8 ) can be used to calculate the perception service.

\subsection{Calculating the gap between perceptions and expectation}

Let fuzzy number Gap be the service quality, between the expectation and perception from all interviewees (Equation 9) of item $i$. 


$$
G a p=M A_{p i} ! M A_{s i}
$$

By using the Equation (2) and (9) the gap between perception and expectation of service quality can be calculated from all interviewees of service $i$.

\subsection{The FAHP methodology (FAHP)}

In this research, though the AHP is to capture the expert's knowledge by perception or preference, the AHP is still able to reflect the human thoughts totally with crisp numbers. The AHP method is a multicriteria method of analysis based on an additive weighting process, in which several relevant attributes are represented through their relative importance.

Academics and professionals, mainly in engineering applications involving financial decisions associated to non-financial attributes (SUN, 2010), have extensively applied AHP. Through AHP, the importance of several attributes is obtained from a process of paired comparison, in which the relevance of the attributes or categories of drivers of intangible assets are matched two-on-two in a hierarchic structure.

The traditional AHP model has some shortcomings, but FAHP, a fuzzy extension of AHP, was developed to solve the hierarchical fuzzy problems and many FAHP methods by various authors are proposed (DURÁN and AGUILO, 2008; CHAMODRAKAS et al., 2010; LEE et al., 2011; SHAVERDI et al., 2014; CHAMOLI, 2015). Therefore, FAHP, which is a fuzzy extension of AHP, is applied to solve the hierarchical fuzzy decision-making problems with fuzzy scales instead of crisp numbers.

The fuzzy triangular scale of preference used in this paper is shows in Table 3. The fuzzy triangular scale of preference used in this paper. The approach used for this was (CHANG, 1996), who developed the application of TFNs (triangular fuzzy numbers) for the linguistic variables of the comparison scale paired to the FAHP and the extended analysis method (analytical measurement) to the values of the paired comparison.

Table 3. Relationship between linguistic variables and their relevance functions

\begin{tabular}{c|ccc}
\hline Linguistic scale of importance & Scale & Fuzzy triangular scale & Fuzzy triangular reciprocal scale \\
\hline Just Equal & - & $(1,1,1)$ & $(1,1,1)$ \\
Equally Important & 1 & $(0,1,2)$ & $(2,1,0)$ \\
Less Important & 2 & $(1,2,3)$ & $(3,2,1)$ \\
Moderately Important & 3 & $(2,3,4)$ & $(4,3,2)$ \\
Very Important & 4 & $(3,4,5)$ & $(5,4,3)$ \\
Extremely Important & 5 & $(4.5,5,5)$ & $(5,5,4.5)$ \\
\hline
\end{tabular}

A comparison of pairs is performed using a ratio scale. The TFNs are used to indicate the relative strength of each pair of elements in the same hierarchy. The scores from the paired comparisons are transformed into linguistic variables, which are represented by TFNs.

We used the method fuzzy AHP proposed by Chang (1996), Kahraman et al. (2004), Kutlu and Ekmekçioğlu (2012), Cho and Lee (2013), Stefano et al., (2015a, 2015b), Mangla, Govindan and Luthra (2017).. The steps to be followed for the application of FAHP are:

Step 1: To form comparisons of pairs of attributes using the fuzzy numbers, which consist of low, medium and higher values at the same level of the hierarchical structure.

Step 2: The value of the fuzzy synthetic extent with respect to the $i^{\text {th }}$ object is defined by Equations 10, 11, 12, and 13: 


$$
\begin{aligned}
& S_{i}=\sum_{j=1}^{m} M_{g i}^{j} \otimes\left[\sum_{i=1}^{n} \sum_{j=1}^{m} M_{g i}^{j}\right]^{-1} \\
& \sum_{j=1}^{n} M_{i j}=\left(\sum_{j=1}^{n} l_{i j}, \sum_{j=1}^{n} m_{i j}, \sum_{j=1}^{n} u_{i j}\right), i=1 ; 2 ; 3 \ldots ., n \\
& \sum_{i=1}^{m} \sum_{j=1}^{n} M_{g i}^{j}=\left(\sum_{i=1}^{m} \sum_{j=1}^{n} l_{i j}, \sum_{i=1}^{m} \sum_{j=1}^{n} m_{i j}, \sum_{i=1}^{m} \sum_{j=1}^{n} u_{i j}\right) \\
& {\left[\sum_{i=1}^{m} \sum_{j=1}^{n} M_{i j}\right]^{-1}=\left(\frac{1}{\sum_{i=1}^{m} \sum_{j=1}^{n} l_{i j}}=\frac{1}{\sum_{i=1}^{m} \sum_{j=1}^{n} m_{i j}}, \frac{1}{\sum_{i=1}^{m} \sum_{j=1}^{n} l_{i j}}\right)}
\end{aligned}
$$

Step 3: The degree of possibility of $M_{2}=\left(l_{2}, m, u_{2}\right) \geq M_{1}=\left(l_{1}, m_{1}, u_{1}\right)$ is set (Equation 14) as:

$$
V\left(M_{2} \geq M_{1}\right)=\sup _{y 2 x}\left[\min \left(\mu_{M_{2}}(x), \mu_{M_{2}}(y)\right)\right]
$$

In addition, it may be equivalent to Equation 15:

$$
V\left(M_{2} \geq M_{1}\right)=\operatorname{hgt}\left(M_{1} \cap M_{2}\right)=\mu_{M_{2}}(d)=\left\{\begin{array}{c}
1 ; \text { if } m_{2} \geq m_{1} \\
0 ; i f l_{1} \geq l_{2} \\
\frac{l_{1}-u_{2}}{\left(m_{2}-u_{2}\right)-\left(m_{1}-l_{1}\right)}, C C
\end{array}\right.
$$

To compare $M_{1}$ and $M_{2}$ are needed the values $V\left(M_{1} \geq M_{2}\right)$ and $V\left(M_{2} \geq M_{1}\right)$

Step 4: The level of possibility for a convex fuzzy number to be greater than $k$ convex fuzzy numbers can be defined by Equation 16 .

$V\left(M \geq M_{1}, M_{2} \ldots, M_{k}\right)=V\left[\left(M \geq M_{1}\right)\right] e\left(M \geq M_{2}\right)$ and $\ldots$. cond $\left(M \geq M_{k}\right)=\min V\left(M \geq M_{i}\right), i=1 ; 2 ; 3 \ldots ; k$

Equation 16 takes the form of Equation 17. For $k=1 ; 2 \ldots ; n ; k \neq i$. Following the weight vector is given by: 


$$
W^{\prime}=\left(d^{\prime\left(A_{1}\right)}, d^{\prime\left(A_{2}\right)} \ldots, d^{\prime\left(A_{n}\right)}\right)^{T}
$$

where $A_{i}(i=1 ; 2 \ldots ; n)$ has $n$ elements.

Step 5: through standardization, Equation 18 normalizes the weight vectors.

$$
W=\left(d\left(A_{1}\right), d\left(A_{2}\right) \ldots, d\left(A_{n}\right)\right)^{T}
$$

where $W$ is a non-fuzzy number.

Step 6: Calculation of global weights (STEFANO et al., 2015) for the sub-criteria. The global weights of sub-criteria are calculated by multiplying the weight of the sub-criteria with the weight of the criteria to which it belongs. They are denoted by $w_{s u b}^{i}=\left(w_{i 1}, w_{i 2} \ldots, w_{i n i}\right)$, where $n_{i}$ is the number of sub-criteria with respect to the $i_{n}$ criterion.

\section{RESULTS}

Data collection was realized during the summer months (December/February) in Santa Catarina, Brazil. Interviews were conducted with 187 guests in a large hotel (by request, the company's name will not be revealed). Of the interviewees, $57 \%$ were female and $43 \%$ male; $17 \%$ have high school, $48 \%$ graduate and $35 \%$ postgraduate qualifications respectfully. The internal consistency test, Cronbach's alpha, which presented a value equal to 0.8852 , was realized. A value of at least 0.70 (between 0 to 1) (HAIR et al., 2006) reflects an acceptable reliability, while recognizing that this value is not an absolute standard. Cronbach's alpha values below 0.70 are accepted if the research is exploratory. Malhotra (2001) considering, the cut-off value to be considered is 0.60 , below this value the author considers that the reliability is poor.

\subsection{Fuzzy SERVQUAL and comparison of gap and global weighted fuzzy AHP}

The result of the scores of Expectations (Expec.) and Perceptions (Perc.), and the gap between expectation and perception are shown in Table 4.

Table 4. The fuzzy scores of expectations and perceptions

\begin{tabular}{c|cccccc}
\hline $\begin{array}{c}\text { Criteria/ } \\
\text { sub-criteria }\end{array}$ & $\begin{array}{c}\text { Fuzzy percep- } \\
\text { tion }\end{array}$ & $\begin{array}{c}\text { Fuzzy expecta- } \\
\text { tion }\end{array}$ & Fuzzy gap & Perception & Expectation & Gap5 \\
\hline Tangibles & $(\mathbf{3 . 7 8 , 4 . 5 0 , 4 . 9 4 )}$ & $(\mathbf{3 . 7 7 , 4 . 4 9 , 4 . 9 4 )}$ & $\mathbf{( - 1 . 1 6 , 0 . 0 1 , 1 . 1 7 )}$ & $\mathbf{4 . 5 1}$ & $\mathbf{4 . 5 0}$ & $\mathbf{0 . 0 1}$ \\
$\mathrm{Sc}_{1}$ & $(3.76,4.48,4.91)$ & $(3.56,4.34,4.89)$ & $(-1.13,0.14,1.36)$ & 4.48 & 4.34 & 0.14 \\
$\mathrm{Sc}_{2}$ & $(3.93,4.61,4.98)$ & $(3.89,4.56,4.90)$ & $(-0.97,0.05,1.09)$ & 4.61 & 4.56 & 0.05 \\
$\mathrm{Sc}_{3}$ & $(3.81,4.51,4.91)$ & $(3.63,4.40,4.95)$ & $(-1.14,0.11,1.28)$ & 4.51 & 4.40 & 0.11 \\
$\mathrm{Sc}_{4}$ & $(3.61,4.35,4.83)$ & $(3.89,4.58,4.96)$ & $(-1.36,-0.23,0.94)$ & 4.35 & 4.58 & -0.23 \\
$\mathrm{Sc}_{5}$ & $(3.84,4.53,4.91)$ & $(3.79,4.51,4.96)$ & $(-1.11,0.02,1.12)$ & 4.53 & 4.51 & 0.02 \\
$\mathrm{Sc}_{6}$ & $(3.52,4.30,4.88)$ & $(3.67,4.41,4.89)$ & $(-1.37,-0.10,1.21)$ & 4.30 & 4.41 & -0.10 \\
$\mathrm{Sc}_{7}$ & $(4.08,4.71,4.97)$ & $(4.05,4.70,4.99)$ & $(-0.92,0.01,0.91)$ & 4.73 & 4.70 & 0.03 \\
$\mathrm{Sc}_{8}$ & $(3.81,4.52,4.93)$ & $(3.71,4.45,4.94)$ & $(-1.12,0.07,1.22)$ & 4.52 & 4.45 & 0.07
\end{tabular}




\begin{tabular}{|c|c|c|c|c|c|c|}
\hline Reliability & $(3.71,4.43,4.87)$ & $(3.80,4,52,4.94)$ & $(-1.23,-0.09,1.07)$ & 4.41 & 4.51 & -0.10 \\
\hline $\mathrm{Sc}_{9}$ & $(3.56,4.30,4.78)$ & $(3.86,4.56,4.95)$ & $(-1.39,-0.26,0.92)$ & 4.30 & 4.56 & -0.25 \\
\hline $\mathrm{Sc}_{10}$ & $(3.60,4.35,4.86)$ & $(3.70,4.43,4.89)$ & $(-1.29,-0.07,1.16)$ & 4.35 & 4.43 & -0.07 \\
\hline $\mathrm{Sc}_{11}$ & $(3.89,4.57,4.93)$ & $(3.92,4.61,4.98)$ & $(-1.10,-0.04,1.00)$ & 4.57 & 4.61 & -0.04 \\
\hline $\mathrm{Sc}_{12}$ & $(3.70,4.41,4.84)$ & $(3.74,4.47,4.94)$ & $(-1.24,-0.06,1.11)$ & 4.41 & 4.47 & -0.06 \\
\hline Assurance & $(3.60,4.37,4.87)$ & $(3.84,4.53,4.93)$ & $(-1.33,-0.16,1.03)$ & 4.38 & 4.53 & -0.15 \\
\hline $\mathrm{Sc}_{13}$ & $(3.79,4.50,4.91)$ & $(3.98,4.65,5.00)$ & $(-1.21,0.16,0.94)$ & 4.50 & 4.65 & -0.15 \\
\hline $\mathrm{Sc}_{14}$ & $(3.40,4 \cdot 20,4.79)$ & $(3.64,4.39,4.89)$ & $(-1.49,-0.19,1.15)$ & 4.19 & 4.39 & -0.20 \\
\hline $\mathrm{Sc}_{15}$ & $(3.83,4.52,4.92)$ & $(3.83,4.50,4.83)$ & $(-1.01,0.03,1.09)$ & 4.52 & 4.50 & 0.02 \\
\hline $\mathrm{Sc}_{16}$ & $(3.49,4.28,4.84)$ & $(3.91,4.60,4.98)$ & $(-1.49,-0.32,0.94)$ & 4.28 & 4.59 & -0.31 \\
\hline Empathy & $(3.48,4.26,4.83)$ & $(3.54,4.30,4.83$ & $(-1.35,-0.04,0.00)$ & 4.26 & 4.30 & -0.04 \\
\hline $\mathrm{Sc}_{17}$ & $(3.48,4.27,4.87)$ & $(3.57,4.32,4.82)$ & $(-1.35,-0.05,1.30)$ & 4.26 & 4.32 & -0.06 \\
\hline $\mathrm{Sc}_{18}$ & $(3.02,3.90,4.65)$ & $(3.31,4,14,4.81)$ & $(-1.79,-0.25,1.34)$ & 3.90 & 4.14 & -0.24 \\
\hline $\mathrm{Sc}_{19}$ & $(3.65,4.40,4.89)$ & $(3.64,4.36,4.81)$ & $(-1.17,0.03,1.25)$ & 4.40 & 4.36 & 0.04 \\
\hline $\mathrm{Sc}_{20}$ & $(3.77,4.49,4.91)$ & $(3.64,4.39,4.88)$ & $(-1.10,0.10,1.28)$ & 4.49 & 4.39 & 0.10 \\
\hline Access & $(3.85,4.55,4.94)$ & $(3.80,4.49,4.89)$ & $(-1.04,0.06,1.14)$ & 4.54 & 4.49 & 0.05 \\
\hline $\mathrm{Sc}_{21}$ & $(3.91,4.61,5.00)$ & $(3.84,4.54,4.93)$ & $(-1.02,0.07,1.16)$ & 4.61 & 4.54 & 0.07 \\
\hline $\mathrm{Sc}_{22}$ & $(3.79,4.49,4.88)$ & $(3.75,4.45,4.84)$ & $(-1.05,0.04,1.13)$ & 4.48 & 4.44 & 0.04 \\
\hline Mean & $(3.69,4.42,4.88)$ & $(3.75,4.47,4.91)$ & $(-1.22,-0.05,1.13)$ & 4.42 & 4.47 & -0.05 \\
\hline
\end{tabular}

The dimensions of service expectation (average scores), can be classified as follows: Assurance (4.53); Reliability (4.51); Tangibles (4.50); Access (4.49) and Empathy. In terms of the items of service expectation, can be classified as follows: Sc7 (provision of food and drink -4.70); Sc13 (resolve guest's complaints); Sc11 (keeps accurate records -4.61); Sc16 (knowledge of employees - 4.59) and; Sc4 (atmosphere and equipment - 4.58).

The dimensions of service perceptions (average scores), follows: Access (4.54); Tangibles (4.51); Reliability (4.41); Assurance (4.38) and; Empathy (4.26). The items of service perception, i.e. : Sc7 (provision of food and drink - 4.73); Sc2 (adequate capacity - 4.61); Sc21 (easy access -4.61); Sc5 (operation of equipment - 4.53) and; Sc8 (appearance of hotel employees - 4.52).

Comparing the service quality expectations with perceptions, we have the top 7 service quality negative gaps (items): Sc16 (-0.31 - knowledge of employees); Sc9 (-0.25 - accurate service; Sc18 (-0.24 - understanding of needs); Sc4 (-0.23 - atmosphere and equipment); Sc14 ( -0.20 - flexibility in services); Sc13 (-0.15 - resolve guest's complaints) and; Sc6 (materials to services). The dimensions "Assurance", "Reliability", "Empathy" obtained negative gaps of -0.15 , $-0.10,-0.04$ respectively.

Comparing the global weight of FAHP (sub-criteria) with the score of expectation and perception (Table 5) it can be observed that the highest and lowest expectations coincide with the weight value. This demonstrated that the two methods could be used simultaneously and thus show satisfactory results. Understanding customers' (PARASURAMAN et al., 1998; HUSSAIN et al., 2015) service expectations is a prerequisite for delivering superior service because they are implicit performance standards that customers use in assessing service quality.

Table 5. Comparison gap and global weight (expectation and perception)

$\begin{array}{lllllll}\text { Criteria } & \text { Sc. } & \text { Expec. } & \text { Local weight (\%) } & \text { Global weight (\%) } & \text { Perc. Local weight Global wei- }\end{array}$ (\%) ght (\%) 


\begin{tabular}{l|lllllll}
\hline & $\mathrm{Sc}_{1}$ & 4.34 & 0.70 & 1.97 & 4.48 & 8.56 & 4.67 \\
C1 (18.89\%) & $\mathrm{Sc}_{2}$ & 4.56 & 3.25 & 6.52 & 4.61 & 18.23 & 8.90 \\
& $\mathrm{Sc}_{3}$ & 4.40 & 1.11 & 2.92 & 4.51 & 10.85 & 5.59 \\
& $\mathrm{Sc}_{4}$ & 4.58 & 3.77 & 7.24 & 4.35 & 5.73 & 2.73 \\
& $\mathrm{Sc}_{5}$ & 4.51 & 2.34 & 4.91 & 4.53 & 15.43 & 6.50 \\
& $\mathrm{Sc}_{6}$ & 4.41 & 1.52 & 3.21 & 4.30 & 4.10 & 3.75 \\
& $\mathrm{Sc}_{7}$ & 4.70 & 4.29 & 8.69 & 4.73 & 23.97 & 9.28 \\
& $\mathrm{Sc}_{8}$ & 4.45 & 1.93 & 3.78 & 4.52 & 13.14 & 5.89 \\
C2 (24.70\%) & $\mathrm{Sc}_{9}$ & 4.56 & 5.88 & 6.52 & 4.30 & 10.00 & 2.30 \\
& $\mathrm{Sc}_{10}$ & 4.43 & 2.16 & 3.49 & 4.35 & 16.73 & 2.73 \\
& $\mathrm{Sc}_{11}$ & 4.61 & 10.49 & 7.61 & 4.57 & 44.86 & 8.12 \\
& $\mathrm{Sc}_{12}$ & 4.47 & 4.36 & 4.35 & 4.41 & 28.39 & 3.63 \\
C3 (36.49\%) & $\mathrm{Sc}_{13}$ & 4.65 & 7.68 & 8.33 & 4.50 & 30.48 & 5.28 \\
& $\mathrm{Sc}_{14}$ & 4.39 & 4.80 & 2.30 & 4.19 & 10.95 & 1.71 \\
& $\mathrm{Sc}_{15}$ & 4.50 & 10.56 & 4.63 & 4.52 & 40.48 & 5.59 \\
& $\mathrm{Sc}_{16}$ & 4.59 & 13.44 & 7.60 & 4.28 & 18.10 & 2.08 \\
C4 (7.02\%) & $\mathrm{Sc}_{17}$ & 4.32 & 2.98 & 1.48 & 4.26 & 20.11 & 1.86 \\
& $\mathrm{Sc}_{18}$ & 4.14 & 0.61 & 1.28 & 3.90 & 12.17 & 1.42 \\
& $\mathrm{Sc}_{19}$ & 4.36 & 1.24 & 1.89 & 4.40 & 33.87 & 3.76 \\
& $\mathrm{Sc}_{20}$ & 4.39 & 2.18 & 2.30 & 4.49 & 46.56 & 4.98 \\
& $\mathrm{Sc}_{21}$ & 4.54 & 9.22 & 5.20 & 4.61 & 75.05 & 4.55 \\
& $\mathrm{Sc}_{22}$ & 4.44 & 3.69 & 3.78 & 4.48 & 24.95 & 4.67 \\
\hline
\end{tabular}

Therefore, customer's expectations for a particular service builds their assessment of service quality. Because, when there is a discrepancy between customers' expectations and management's understanding of customer expectations, perceived service quality will be affected. Management's accuracy is one kind of quality gap. Even when management fully understands customer expectations, service quality problems may still occur.

Many organizations seeking to improve quality concentrate most of their efforts on techniques and instruments behavior that cannot lead to the desired results. These service organizations need to understand the culture for quality. I.e., the most important values for quality acquired by managers and employees. Values can be identified by observing the management process, technological system, and the human relationship in the organization.

\section{CONCLUSION}

This paper aimed to exhibit the importance of services quality in a hotel, considering the perception versus the expectation, through the fuzzy SERVQUAL and FAHP. The results showed that the quality of services provided in various items that expectation be above perception $\left(\right.$ gap $_{5}$ ). From these findings, the company may act in areas related to their points of difference between expectation and perception of quality of services provided. Investing in the maintenance of positive factors considered and reassessment of the procedures conflicting aspects.

However, it was also shown in this study that it is especially important for service companies to monitor the quality in meeting the needs and expectations of its customers, thereby creating competitive advantage. Companies first must examine the impact of their service quality provision on customer's response, including intentions signaling behaviors that are potentially favorable or unfavorable to the company. As limitation of the study highlight the sampling, i.e. just a hotel. 
Regarding the use methods (FSERVQUAL and FAHP), these proved to be adequate for assessing the quality of services. For future research, the use of multicriteria methods associated with fuzzy logic and the proposal of indicators to assess the quality of services is suggested.

\section{REFERENCES}

AKBABA, A. Measuring service quality in the hotel industry: a study in a business hotel in Turkey. Hospitality Management, v. 25, p. 170-192, 2006.

ALNSOUR, M.S.; TAYEH, B.A.; ALZYADAT, M.A. Using SERVQUAL to assess the quality of service provided by Jordanian telecommunications sector. International Journal of Commerce and Management, v. 24, n. 3, p. 209-218, 2014.

AYAĞ, Z. A fuzzy AHP-based simulation approach to concept evaluation in a NPD environment. IIE Transactions, v. 37, p. 827-842, 2005.

BARABINO, B.; DEIANA, E.; TILOCCA, P. Measuring service quality in urban bus transport: a modified SERVQUAL approach. International Journal of Quality and Service Sciences, $v$. 4, n. 3, p. 238-252, 2012.

BASFIRINCI, C.; MITRA, A. A cross cultural investigation of airlines service quality through integration of Servqual and the Kano model. Journal of Air Transport Management, v. 42, p. 239-248, 2015.

BITNER, M.J.; HUBBERT, A.R. Encounter satisfaction vs. overall satisfaction and quality. Rust, T.; Oliver R.L. (Eds.), Service Quality: New Directions in Theory and Practice, Sage Publications, New York, 72-94, 1994.

BÜYÜKÖZKAN, G.; ÇIFÇI, G. A combined fuzzy AHP and fuzzy TOPSIS based strategic analysis of electronic service quality in healthcare industry. Expert Systems with Applications, v. 39, p. 2341-2354, 2012.

BÜYÜKÖZKAN, G.; ÇIFÇI, G.; GÜLERYÜZ, S. Strategic analysis of healthcare service quality using fuzzy AHP methodology. Expert Systems with Applications, v. 38, n. 8, p. 9407-9424, 2011.

CABER, M.; ALBAYRAK, T. Assessing daily tour service quality: A proposal for a DAILYSERV scale. Journal of Destination Marketing \& Management, v. 7, p. 18-25, 2018.

CALABRESE. A. Service productivity and service quality: a necessary trade-off. International Journal Production Economic, v. 135, n. 2, p. 800-812, 2012.

CHAMODRAKAS, I.; BATIS, D.; MARTAKOS, D. Supplier selection in electronic marketplaces using satisficing and fuzzy AHP. Expert Systems with Applications, v. 37, p. 490-498, 2010.

CHAMOLI, S. Hybrid FAHP (fuzzy analytical hierarchy process)-FTOPSIS (fuzzy technique for order preference by similarity of an ideal solution) approach for performance evaluation of the $\checkmark$ down perforated baffle roughened rectangular channel. Energy, v. 84, p. 432-442, 2015.

CHANG, D-Y. Applications of the extent analysis method on fuzzy AHP. European Journal of Operational Research, v. 95, n. 3, p. 649-655, 1996. 
CHARLES, V.; Kumar, M. Satisficing data envelopment analysis: an application to SERVQUAL efficiency. Measurement, v.51, p. 71-80, 2014.

CHO, J.; LEE, J. Development of a new technology product evaluation model for assessing commercialization opportunities using Delphi method and fuzzy AHP approach. Expert Systems with Applications, n. 40, v. 13, p. 5314-5330, 2013.

CHOU, C.-C.; LIU, L.-J.; HUANG, S.-F.; YIH, J.-M.; HAN, T.-C. An evaluation of airline service quality using the fuzzy weighted SERVQUAL method. Applied Soft Computing, v. 11, n. 2, p. 21172128, 2011.

CHOUDHURY, K. Service quality and customers' purchase intentions: an empirical study of the Indian banking sector. International Journal of Bank Marketing, v. 31, n. 7, p. 529-543, 2013.

CHOUDHURY, K. Evaluating customer-perceived service quality in business management education in India: a study in TOPSIS modeling. Asia Pacific Journal of Marketing and Logistics, v. 27, n. 2, p. 208-225, 2015.

CHUANG, S.-H.; LIN, H.-N. Co-creating e-service innovations: theory, practice, and impact on firm performance. International Journal of Information Management, v. 35 n. 3, p. 277-291, 2015.

CULIBERG, B. Identifying service quality dimensions as antecedents to customer satisfaction in retail banking. Economic and Business Review, v. 12, n. 3, p. 151-166, 2010.

DAS, G. Linkages of retailer awareness, retailer association, retailer perceived quality and retailer loyalty with purchase intention: a study of Indian food retail brands. Journal of Retailing and Consumer Services, v. 21, n. 3, p. 284-292, 2014.

DURÁN, O.; AGUILO, J. Computer-aided machine-tool selection based on a Fuzzy-AHP approach. Expert Systems with Applications, v. 34, p. 1787-1794, 2008.

FERGUSON, J.M.; ZAWACKI R.A. Service quality: a critical success factor for IS organizations information strategy. The Executive 's Journal, v. 9, n. 2, p. 24-30, 1993.

GHOBADIAN, A.; SPELLER, S.; JONES, M. Service quality: concepts and models. International Journal of Quality \& Reliability Management, v. 11, n. 90, p. 43-66, 1994.

GOLDSTEIN, S.M.; JOHNSTON, R.; DUFFY, J.; RAO, J. The service concept: the missing link in service design research? Journal of Operations Management, v. 20, n. 2, p. 121-134, 2002.

GRÖNROOS, C. The relationship marketing process: communication, interaction, dialogue, value. Journal of Business \& Industrial Marketing, v. 19, n. 2, p. 99-113, 2004.

HAIR, JR J.F.; BLACK, W.C.; BABIN, B.J.; ANDERSON, R.E.; TATHAM, R.L. Análise multivariada de dados. 5. ed. Porto Alegre: Bookman, 2006.

HUSSAIN, R.; AL NASSER, A.; HUSSAIN, Y.K. Service quality and customer satisfaction of a UAEbased airline: an empirical investigation. Journal of Air Transport Management, v. 42, p. 167-175, 2015. 
JOHNSTON, R. The determinants of service quality: satisfiers and dissatisfiers. International Journal of Service Industry Management, v. 6, n. 5, pp. 53-71, 1995.

JOHNSTON, R. Service operations management: return to roots. Internacional Journal of Operations \& Production Management, v. 25, n. 12, p. 1278-1297, 2005.

JOHNSTON, R.; MICHEL, S. Three outcomes of service recovery: Customer recovery, process recovery and employee recovery. International Journal of Operations \& Production Management, v. 28, n. 1, p. 79-99, 2008.

KAHRAMAN, C.; CEBECI, U.; RUAN, D. Multi-attribute comparison of catering service companies using fuzzy AHP: The case of Turkey. International Journal of Production Economics, v. 87, n. 2, p. 171-184, 2004

KANG, H.; BRADLEY, G. Measuring the performance of IT services: An assessment of SERVQUAL. International Journal of Accounting Information Systems, v. 3, n. 3, p. 151-164, 2002.

KETTINGER, W.J.; LEE, C.C. Perceived service quality and user satisfaction with the information services function. Decision Science, v. 25, n. 5, p. 737-766, 1994.

KUTLU, A.C.; EKMEKÇıOĞLU M. Fuzzy failure modes and effects analysis by using fuzzy TOPSISbased fuzzy AHP. Expert Systems with Applications, v. 39, n. 1, p. 61-67, 2012.

LADHARI, R.; PONS, F.; BRESSOLLES, G.; ZINS, M. Culture and personal values: how they influence perceived service quality. Journal of Business Research, v. 64, p. 951-957, 2011.

LEE, S.K.; MOGI, G.; LEE, S.K.; KIM J.W. Prioritizing the weights of hydrogen energy technologies in the sector of the hydrogen economy by using a fuzzy AHP approach. International Journal of Hydrogen Energy, v. 36, n. 2, p. 1897-1902, 2011.

LI, R.J. Fuzzy method in group decision-making. Computers and Mathematics with Applications, v. 38, n. 1, p. 91-101, 1999.

LI, T.-S.; HUANG, H.-H. Applying TRIZ and Fuzzy AHP to develop innovative design for automated manufacturing systems. Expert Systems with Applications, v. 36, n. 4, p. 8302-8312, 2009.

LIU, R.; CUI, L.; ZENG, G.; WU, H.; WANG, C.; YAN, S.; YAN, B. Applying the fuzzy SERVQUAL method to measure the service quality in certification \& inspection industry. Applied Soft Computing, v. 26, p. 508-512, 2015.

LUPO, T. A fuzzy ServQual based method for reliable measurements of education quality in Italian higher education area. Expert Systems with Applications, v. 40, n. 17, p. 7096-7110, 2013.

LUPO, T. Fuzzy ServPerf model combined with ELECTRE III to comparatively evaluate service quality of international airports in Sicily. Journal of Air Transport Management, v. 42, p. 249-259, 2015.

MALHOTRA, N. Pesquisa de marketing: uma orientação aplicada. 3. ed. Bookman. Porto Alegre, 2001.

MANGLA, S.K.; GOVINDAN, K.; LUTHRA, S. Prioritizing the barriers to achieve sustainable consumption and production trends in supply chains using fuzzy Analytical Hierarchy Process. Journal of Cleaner Production, v. 151, p. 509-525, 2017. 
NEGOITA, C.V. Expert systems and fuzzy systems. Menlo Park, California: The Benjamin/ Cummings, 1985.

OZRETIC-DOSEN, D.; ZIZAK, I. Measuring the quality of banking services targeting student population. EuroMed Journal of Business, v. 10, n. 1, p. 98-117, 2015.

PARASURAMAN, A.; ZEITHAML, V.; BERRY, L. A conceptual model of service quality and its implications for future research. Journal of Marketing, v. 49, n. 4, p. 41-50, 1985.

PARASURAMAN, A.; ZEITHAML, V.; BERRY, L.L. SERVQUAL. A multiple-item scale for measuring consumer perceptions of service quality. Journal of Retailing, v. 64, n. 1, p. 12-40, 1988.

PARASURAMAN, A.; ZEITHAML, V.; BERRY, L.L. Alternative scales for measuring service quality: a comparative assessment based on psychometric and diagnostic criteria. Journal of Retailing, v. 70, n. 3, p. 201-30, 1994.

PARASURAMAN A. Customer service in business-to-business markets: an agenda for research. Journal of Business \&Industrial Marketing, v. 13, n. 4/5, p. 309-321, 1998.

PITT, L.F.; WATSON, R.T.; KAVAN C.B. Service quality: a measure of information systems effectiveness. MIS Quarterly, v. 19, n. 2, p. 173-187, 1995.

RANDS, T. Information technology as a service operation. Journal of Information Technology, $v$. 7, n. 4, p. 189-201, 1992.

REZAEI, J. et al. Quality assessment of airline baggage handling systems using SERVQUAL and BWM. Tourism Management, v. 66, p. 85-93, 2018.

ROGER-MONZÓ, V.; MARTÍ-SÁNCHEZ, M.; GUIJARRO-GARCÍA, M. Using online consumer loyalty to gain competitive advantage in travel agencies. Journal of Business Research, v. 68, n. 7, p. 1638-1640, 2015.

SHAVERDI, M.; HESHMATI, M.R.; RAMEZANI, I. Application of Fuzzy AHP approach for financial performance evaluation of Iranian petrochemical sector. Procedia Computer Science, v. 31, p. 995-1004, 2014.

SNOJ, B.; KORDA, A.P.; MUMEL, D. The relationships among perceived quality, perceived risk and perceived product value. Journal of Product \& Brand Management, v. 13, n. 3, p. 156-167, 2004.

STEFANO, N.M.; CASAROTTO FILHO, N.; BARICHELLO, R. Management of Electronic Journals using Fuzzy AHP Methodology. Latin American Transactions, IEEE, v. 13, n. 1, p. 330-336, 2015a.

STEFANO, N.M.; CASAROTTO FILHO, N.; BARICHELLO, R.; SOHN, A.P. A fuzzy SERVQUAL based method for evaluated of service quality in the hotel industry. Procedia CIRP, v. 30, p. 433438, 2015b.

STUART, F. I.; TAX, S. Towards an Integrative approach to designing service experiences: Lessons learned from the theatre. Journal of Operations Management, v. 22, p. 609-627, 2004.

SUN, C.-C. A performance evaluation model by integrating fuzzy AHP and fuzzy TOPSIS methods. Expert Systems with Applications, v. 37, p. 7745-7754, 2010. 
TAVAKOL, M.; DENNICK, R. Making sense of Cronbach's alpha. International Journal of Medical Education, 2, pp. 53-55, 2011.

UDO, G.J.; BAGCHI, K.K.; KIRS, P.J. Using SERVQUAL to assess the quality of e-learning experience. Computers in Human Behavior, v. 27, n. 30, p. 1272-1283, 2011.

SANDMANN, W. Quantitative fairness for assessing perceived service quality in queues. Operational Research, v. 13, n. 2, p. 153-186, 2013.

WILKINS, H.; MERRILEES, B.; HERINGTON, C. Towards an understanding of total service quality in hotels. Hospitality Management, v. 26, p. 840-853, 2007.

YEE, R.W.Y.; LEE, P.K.C.; YEUNG, A.C.L.; CHENG, T.C.E. The relationships among leadership, goal orientation, and service quality in high-contact service industries: an empirical study. International Journal Production Economic, v. 124, n. 2, p. 452-464, 2010.

ZADEH, L.A. Fuzzy Sets. Information and Control, v. 8, n. 3, p. 338-353, 1965.

ZADEH, L.A. Fuzzy logic, neural network, and soft computing. Communications of the ACM, 37, pp. 77-84, 1994.

ZEHENDNER, E.; FEILLET D. Benefits of a truck appointment system on the service quality of inland transport modes at a multimodal container terminal. European Journal Operational Research, v. 235, n. 2, p. 461-469, 2014.

ZHANG, C.; XING, P. A research on service quality decision-making of Chinese communications industry based on quantum game. Physica A: Statistical Mechanics and its Applications, v. 432, p. 9-15, 2015.

ZIMMERMANN, H. J. Fuzzy set theory and its applications. Massachusetts: Kluwer, 1996.

\section{Contribution of authors}

\begin{tabular}{|c|c|c|c|}
\hline Contribution & [Author 1] & [Author 2] & [Author 3] \\
\hline $\begin{array}{c}\text { 1. Definition of research problem } \\
\text { 2. Development of hypotheses or research questions (em- } \\
\text { pirical studies) }\end{array}$ & $\mathrm{V}$ & & $\mathrm{V}$ \\
\hline $\begin{array}{c}\text { 3. Development of theoretical propositions } \\
\text { (theoretical work) }\end{array}$ & $\mathrm{V}$ & & \\
\hline 4. Theoretical foundation / Literature review & $\mathrm{V}$ & $\mathrm{V}$ & \\
\hline 5. Definition of methodological procedures & $\mathrm{v}$ & & \\
\hline 6. Data collection & $\mathrm{V}$ & & \\
\hline 7. Statistical analysis & $\mathrm{V}$ & $\mathrm{V}$ & \\
\hline 8. Analysis and interpretation of data & $\mathrm{v}$ & & \\
\hline 9. Critical revision of the manuscript & $\mathrm{V}$ & & $\mathrm{V}$ \\
\hline 10. Manuscript writing & $\mathrm{V}$ & & \\
\hline 11. Other (please specify) & & & \\
\hline
\end{tabular}

